\title{
DISTRIBUTION AND FATE OF INTRAVENOUSLY ADMINISTERED MODIFIED HUMAN GLOBIN AND ITS EFFECT ON BLOOD VOLUME. STUDIES UTILIZING I ${ }^{181}$ TAGGED GLOBIN ${ }^{1}$
}

\author{
By SOLOMON A. BERSON, ROSALYN S. YALOW, JOSEPH POST, LAWRENCE H. \\ WISHAM, KATHARINA N. NEWERLY, MANUEL J. VILLAZON, AND \\ OSCAR N. VAZQUEZ
}

\author{
(From the Radioisotope Unit and the General Medical Research Laboratory of the Veterans \\ Administration Hospital, Bronx, New York. N. Y.)
}

(Submitted for publication July 25, 1952; accepted October 1, 1952)

The need for blood substitutes adequate to combat the fall in circulating volume in shock continues to stimulate search for high molecular weight compounds which might serve as plasma expanders. Globin, derived from human red blood cells, has been suggested for this purpose $(1,2)$. While considerable study with this substance is being pursued in various laboratories $(1-7)$, there have been few published reports dealing with its use as a blood volume expander (1).

\section{METHODS}

The present investigation was approached along two lines:

1) Study of the fate and distribution of globin. Plasma and urine were analyzed at frequent intervals following the intravenous administration of tracer doses of $I^{121}$ tagged globin accompanied by varying amounts of uniodinated globin. In vivo assay over the liver following the administration of the tagged globin was also performed in an attempt to localize the organ site of accumulation and breakdown. The disappearance rates of $I^{131}$ tagged globin and albumin from intramuscular, subcutaneous, and intracutaneous sites of injection were determined for the purpose of comparing vascular permeability to the two proteins.

2) Blood volume studies with $P^{23}$ tagged erythrocytes were performed during and after the intravenous administration of infusions of $\mathbf{3 2}$ and $\mathbf{4 8}$ grams of globin.

\section{Radioiodinated proteins}

Modified human globin ${ }^{2}$ was iodinated with a mixture of $\mathrm{I}^{131}$ and $\mathrm{I}^{127}$ at $\mathrm{pH} 8.0$ according to the method of Pressman and Eisen (9) and then dialyzed against frequently changed

1 Reviewed in the Veterans Administration and published with the approval of the Chief Medical Director. The statements and conclusions published by the authors are the results of their own study and do not necessarily reflect the opinion or policy of the Veterans Administration.

2 Modified human globin was generously supplied by Sharp and Dohme, Incorporated, Glenolden, Pennsylvania. The preparation and characteristics of this protein have been described ( 8 ). solutions of isotonic saline solution for approximately 72 hours. Assuming uniform distribution, the tagged protein contained 1 to 2 atoms of iodine per molecule of globin, based on its molecular weight of 34,000 . At the time of use the activity ranged from 0.5 to $10.0 \mu \mathrm{C} \mathrm{I}^{182}$ per mgm. nitrogen. Iodinated globin was passed through Seitz filters and sterility was confirmed by culture before use. The administration of $25 \mathrm{mgm}$. of tagged protein to 2 rabbits failed to elicit evidence of toxicity within 72 hours.

Studies with various proteins have shown that at the level of iodination obtained, significant changes in the immunological properties of the protein do not occur (10). No significant differences between the dialyzed iodinated globin and the uniodinated globin used in this study were observed in the ultracentrifuge ${ }^{3}$ and the electrophoretic pattern of a 1:1 mixture of globin and globin-iodine showed a single peak identical to that of globin alone. Ninety to ninety-seven per cent of the radioactivity was present in the precipitate after treatment with trichloracetic acid. After 3 hours of incubation of globin $I^{121}$ with whole blood at $38^{\circ} \mathrm{C}$. there was no increase in the nonprecipitable activity nor was there any detectable radioactivity in the centrifuged erythrocyte column above that attributable to trapped plasma.

Albumin $I^{121}$ was prepared in the same manner or was obtained from Abbott Laboratories and dialyzed until the protein-free activity was less than 1 per cent of the total activity. Electrophoretic and ultracentrifugal analyses revealed no significant differences between this material and native albumin.

Subjects of these studies were convalescent and ambulant patients of the Veterans Administration Hospital, Bronx. None were acutely ill or in shock. All subjects received 5 drops of Lugol's solution 3 times per day during the studies. Assay over the neck showed this to be effective in inhibiting thyroid uptake of $I^{121}$.

\section{Assay of radioactivity in plasma and urine}

Approximately $5 \mathrm{ml}$. of isotonic saline solution containing 50 to $100 \mu \mathrm{C} \mathrm{I}{ }^{121}$ and 10 to $30 \mathrm{mgm}$. protein was injected intravenously in the tracer studies. In vivo assay over the site of injection ruled out any invisible extravascular leak. Methods used in the assay of radioactivity

${ }^{3}$ Thanks are due to Dr. Kurt G. Stern, Brooklyn Polytechnic Institute for the ultracentrifuge analyses. 
of the administered doses, whole blood specimens, plasma and erythrocyte fractions and urine were identical with those previously described for $\mathrm{KI}^{\mathrm{m}}(11)$ and albumin $\mathrm{I}^{12}$ (12). The plasma and erythrocytes were separated after centrifugation for 10 minutes at $1000 \mathrm{~g}$. Erythrocyte assays were done for all the points of curve I. B. and all but the last point of curve H. W. in Figure 1. The plasma activities at these times were corrected by subtracting from them 1.5 times the erythrocyte concentrations ${ }^{*}$ after deduction of 5 per cent trapped plasma (13). I Is1 could be assayed in the presence of $\mathrm{P}^{\infty}$ without correction by using a bismuth walled gamma counter and thick glass Marinelli beakers. The total activity, trichloracetic acidprecipitable activity and the activity in the filtrate were determined in all urine specimens. Carrier globin or al-

4 This factor was based on the assumption that the erythrocyte penetrable fraction was distributed uniformly with regard to its concentration in plasma water and erythrocyte water as is the case with iodide (14). If the protein-free fraction were some molecule such as mono or diiodotyrosine which entered the erythrocytes in lower concentration, then this correction is actually not sufficient. bumin was added to these specimens to facilitate precipitation of the minute amounts of protein bound $I^{\text {tat }}$ present.

\section{Determination of globin concentrations}

Globin nitrogen in serum was determined by the method of Kendall and Abell as described by Sample, Strumia, and Satta (15). The factor $7.5 \times \mathrm{N}$ was used in calculating the globin concentrations. Recovery experiments revealed that $80 \pm 3$ per cent of the added globin could be accounted for in serum. The globin concentrations therefore were corrected by multiplying the observed values by 1.25 . Only an occasional cloudiness without visual precipitate was noted on adding the reagents to globin-free serum.

\section{Assay of relative change in radioactivity of liver}

In vivo counting over the liver was performed with a bismuth walled Geiger counter enclosed in a 3/4" lead housing containing an open window measuring $5^{\prime \prime} \times 1^{\prime \prime}$ and placed $43 / 4$ " above the right upper quadrant of the abdomen of recumbent subjects. The position of the counter was kept unchanged during each period and a tapered lead shield which extended from the housing craniad to the

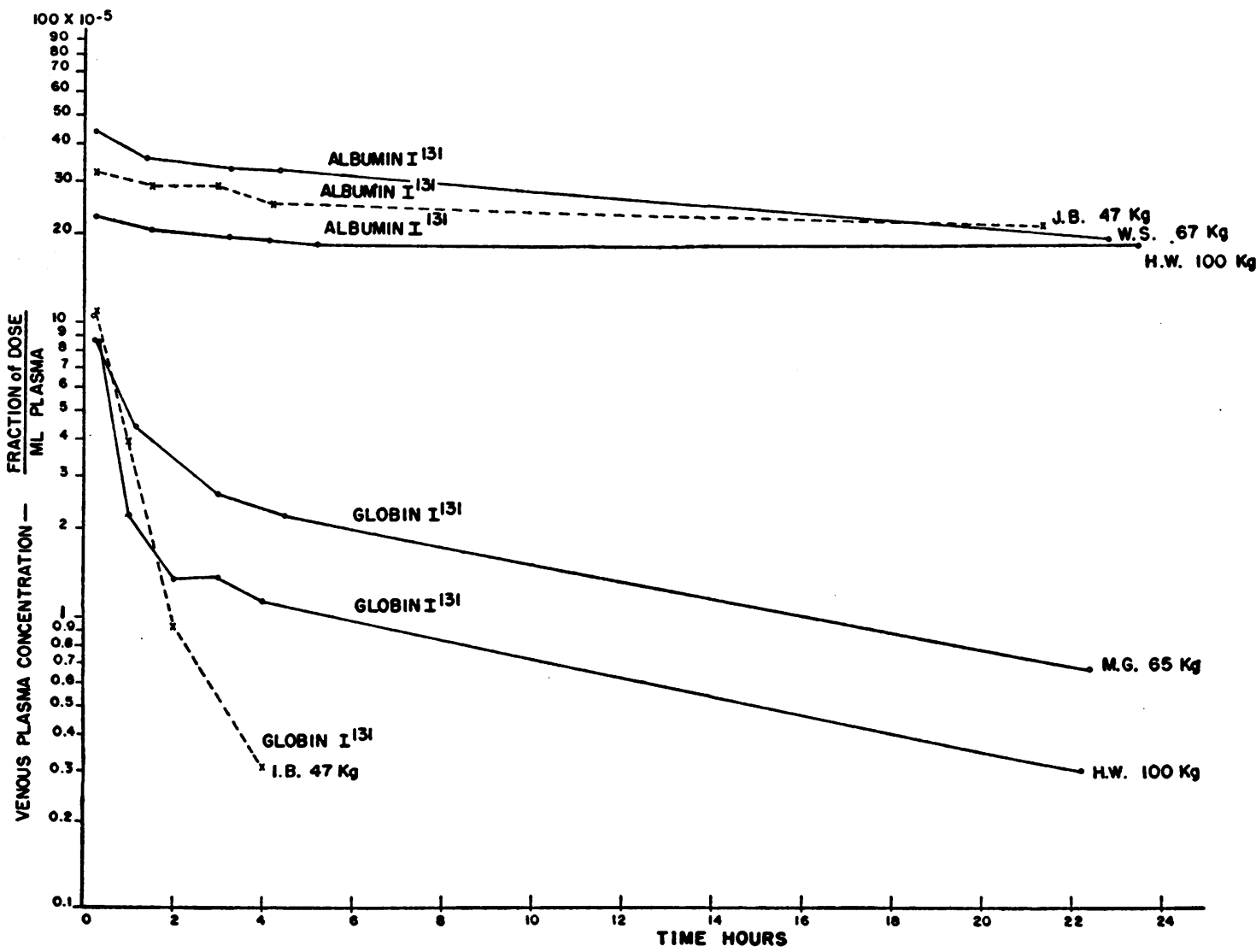

Fig. 1. Venous Plasma Concentrattons Expressed as Fraction of the Dose Administered Per ml. of Plasma following the Intravenous Administration of Tracer Doses of ${ }^{19}$ Tagged Human Serum Albumin and Modified Human Globin 
tube remained in contact with the skin. The scaler circuit leading from the counter fed into a Streeter-Amet printing register which automatically recorded the cumulative counts at one minute intervals.

\section{Tissue clearance}

The rate of disappearance of globin $\mathrm{I}^{181}$ and albumin $\mathrm{I}^{121}$ from intracutaneous, subcutaneous and intramuscular sites of injection in the lower extremities was studied by techniques similar to those previously described for $\mathrm{Na}^{24}(16)$. One-tenth ml. of solution containing $1-2 \mu \mathrm{C} \mathrm{I} \mathrm{I}^{181}$ and 100 to 1000 gamma of protein was injected in these studies.

\section{Blood volume determinations}

Initial total blood volumes, plasma volumes and red cell volumes were estimated from the dilution of $P^{*}$ tagged erythrocytes $(17,18)$. The $\mathrm{P}^{20}$ activity was assayed using a thin glass walled beta gamma counter. Corrections were made for $\mathrm{I}^{212}$ activity, when present, by simultaneous assay of blood specimens in the gamma counter. The maximum correction necessary in case H. W. was less than 10 per cent and in case I. B. less than $11 / 2$ per cent of the $\mathrm{P}^{20}$ counting rates. A straight line describing the exponential biological decay curve of the tagged cells was established during a suitable control period. The changes produced by the infusion of globin and albumin were evaluated from the deviation of subsequent points from this line according to methods previously described (18). Changes in plasma volume were also independently calculated from the hematocrit and hemaglobin values according to the formula :

$$
\frac{P V_{n}}{P V_{0}}=\frac{h g b_{0} \times\left(1-h_{c t}\right)}{h g b_{n} \times\left(1-\text { hct }_{0}\right)}
$$

where $\mathrm{PV}_{\text {. is initial plasma volume and }} \mathbf{P V}_{\mathrm{n}}$ is any subsequent plasma volume (19). Hematocrits were performed in Wintrobe tubes spun for 30 minutes at $2000 \mathrm{~g}$. Hemoglobin determinations were performed according to the method of Wong (20).

\section{RESULTS}

The rates of disappearance from plasma of intravenously injected tracer doses of globin $\mathrm{I}^{\mathbf{1 3 1}}$ were very rapid when compared with those of albumin $\mathrm{I}^{181}$ (Figure 1). Thus at 12 minutes approximately two thirds of the globin activity had already disappeared from the intravascular circulation. By the following day only insignificant concentrations of circulating activity were observed.

At one hour (but not at 12-20 minutes) following injection of tracer doses of globin $\mathrm{I}^{\mathbf{1 8 1}}$, the red blood cells already contained activity well in excess of that which could be accounted for on the basis of trapped plasma. It should be appreciated that if the plasma correction factor, derived from the erythrocyte assays, were too small, the globin $I^{131}$ curves would be even lower and steeper than shown since the ratios of erythrocyte activity/ plasma activity increased with time. In the studies with albumin $\mathrm{I}^{131}$ significant activity in the erythrocytes was not encountered at any time.

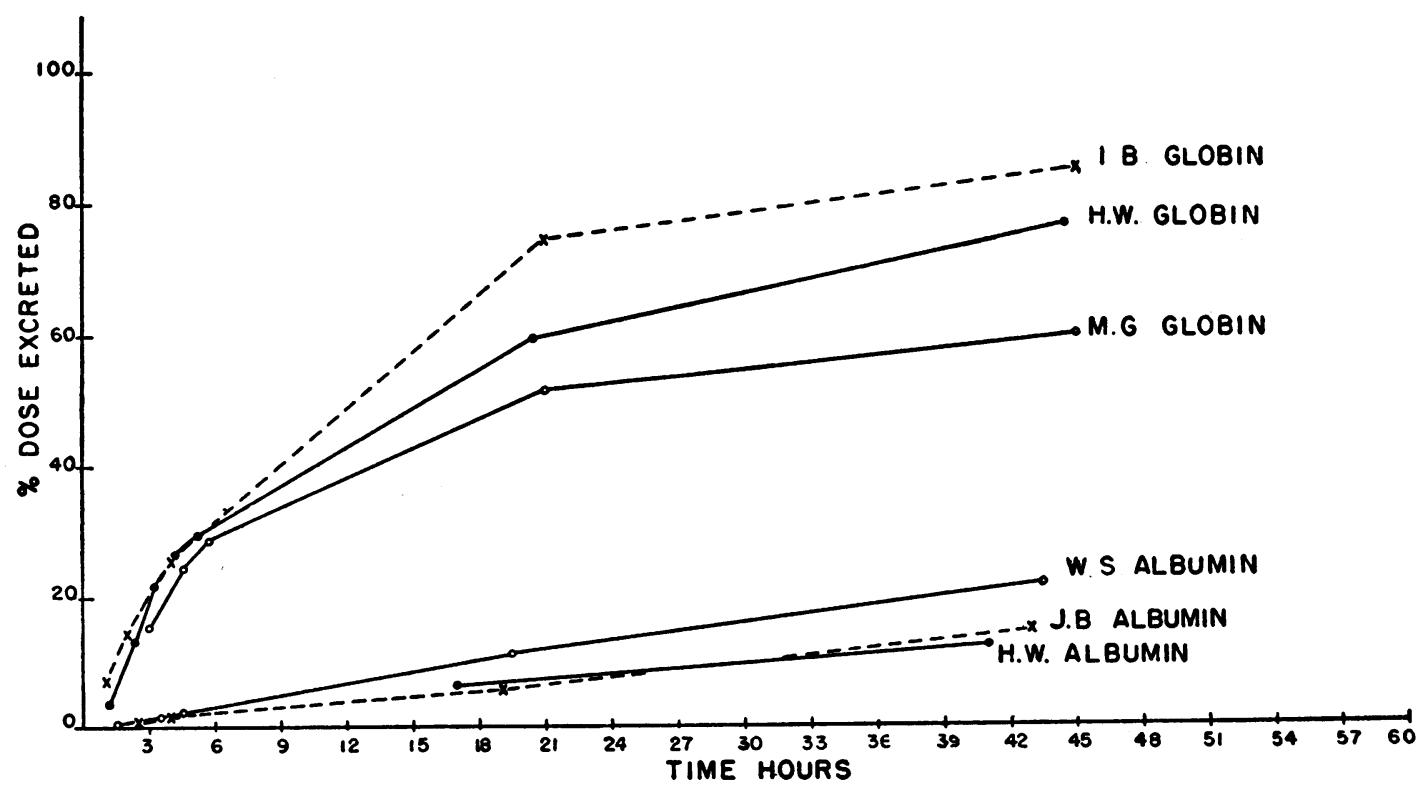

Fig. 2. Cumulative Urinary Excrettons of I ${ }^{\text {Im }}$ Following the Intravenous Administration of Tracer Doses of Isi Tagged Human Serum Albumin and Modified Human Globin 


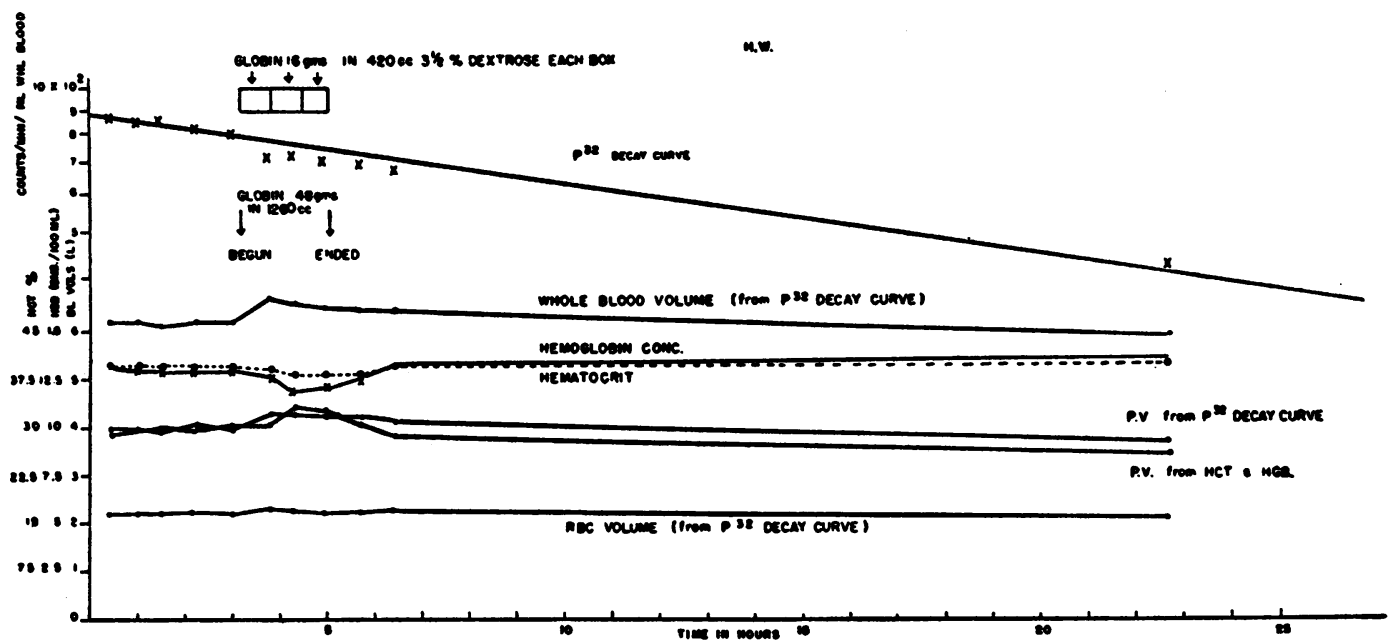

Fig. 3. Biological Decay Curve of Ps Labeled Erythrocytes, Hemoglobin Concentration, Hematocrit and Calculated Blood Volumes Before, During and After Intravenous Administration of 48 G. of Globin in Subject H. W.

The cumulative urinary excretions of $\mathrm{I}^{131}$ expressed as per cent of the administered doses in these experiments amounted to approximately 32 per cent in the first 6 hours and 50-80 per cent in the first 21 hours (Figure 2) even though the collections in 2 of the patients (H. W. and M. G.) were known to be incomplete. Following the albumin $I^{131}$ injections, only protein-free activity in the urine was detectable and did not exceed 10 per cent of the dose over the first 24 hours. Following injection of the tracer doses of globin $\mathrm{I}^{181}, 3$ per cent to 10 per cent of the $\mathrm{I}^{131}$ was precipitable by trichloracetic acid in the urine passed up to four hours after injection. The urine passed after four hours did not contain more than 2 per cent precipitable $\mathrm{I}^{131}$. Since the half time for nor-

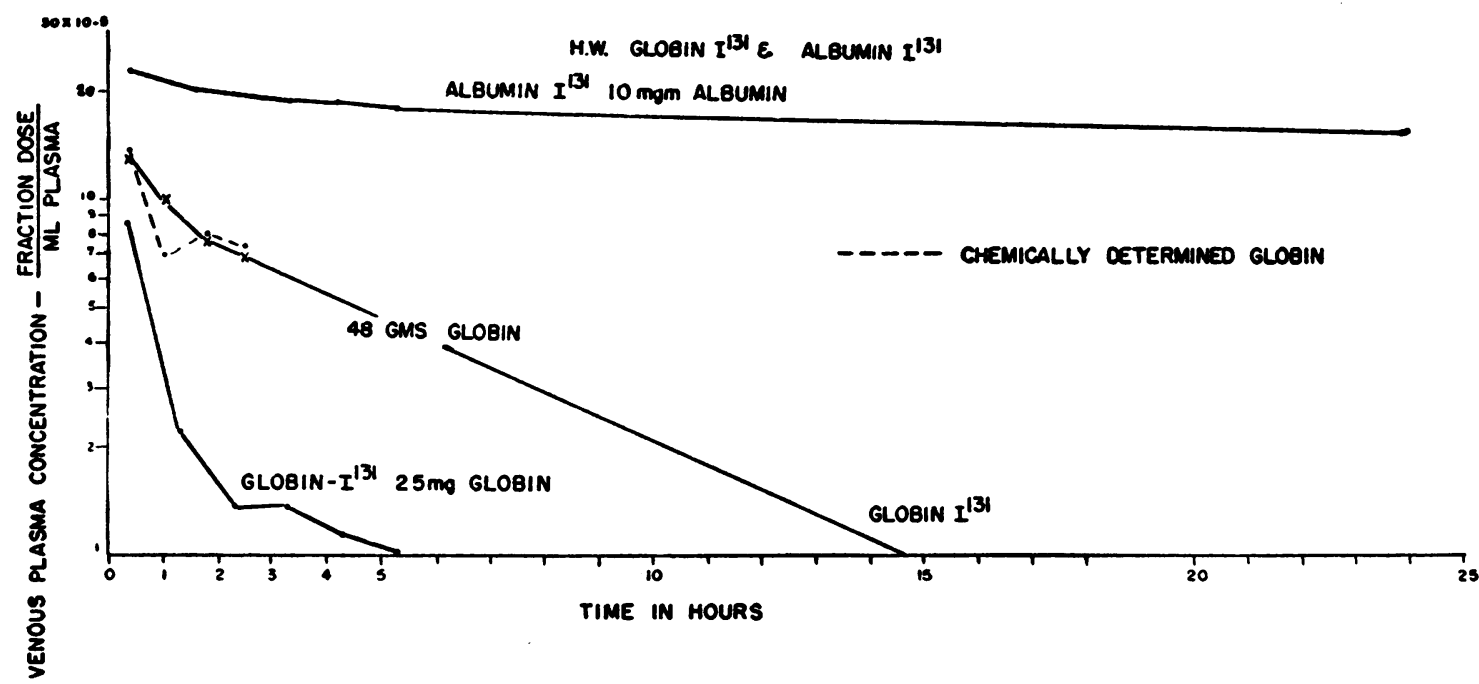

Fig. 4. Venous Plasma Concentrations of Untagged (Interrupted Line) and Tagged Globin Following the Intravenous Administratton of Globulin-I ${ }^{21}$ at Different Carrier Levels and of Tagged Albumin After a Tracer Dose of Albumin-I Im In Subject H. W.

The 19 hour concentration of globin $\mathrm{I}^{212}\left(0.52 \times 10^{-5}\right)$ was too low to be shown on the same scale. If extrapolated, the globin $I^{121}$ line would pass through that point. At the same time serum globin was not detectable by chemical analysis. 
mal renal removal of $\mathrm{I}^{181}$ as iodide is approximately 9 hours (11) when the thyroid uptake is blocked by iodine medication, the urinary excretion curves in the globin cases indicate that the $\mathrm{I}^{131}$ was very rapidly released from the protein. This confirms the impression obtained from the erythrocyte assays, that an appreciable fraction of the circulating activity was in non-protein bound form within an hour or two after injection.

The $\mathrm{P}^{32}$ decay curve and the changes in hematocrit, hemoglobin, and blood volume during and following the intravenous infusion of $48 \mathrm{~g}$. of globin in $1260 \mathrm{cc}$. of $3 \frac{1}{2}$ per cent dextrose solution over a 2 hour period in subject $\mathrm{H}$. W. are shown in Figure 3. A control study with 1000 cc of 5 per cent glucose in water performed in this patient showed no changes in the blood volumes. The maximum plasma volume increase during the globin infusion was 8 per cent falling to 5 per cent two hours after the infusion was completed. This is to be compared with a plasma volume increase of 35 per cent accompanying the intravenous administration of $50 \mathrm{~g}$. of salt poor human serum albumin in $200 \mathrm{cc}$ of buffered diluent in this same subject. The $\mathrm{P}^{32}$ decay curve from which the latter value was derived is published elsewhere (18).

The venous plasma concentration versus time relationship for globin $\mathrm{I}^{181}$ administered during the infusion of globin (after $16 \mathrm{~g}$. had already been given) is shown in Figure 4 together with similar curves for the tracer doses of globin $\mathrm{I}^{\mathbf{1 3 1}}$ and albumin $\mathrm{I}^{131}$ given without other protein. The concentrations of chemically determined globin during and after this infusion are also shown. The higher initial values and lower decline in concentration of globin $\mathrm{I}^{131}$ when administered together with a large amount of carrier globin as compared to the tracer doses alone are obvious. It should be noted, however, that the extrapolated globin $\mathrm{I}^{131}$ concentration at zero time even in the former case does not equal the early albumin con-

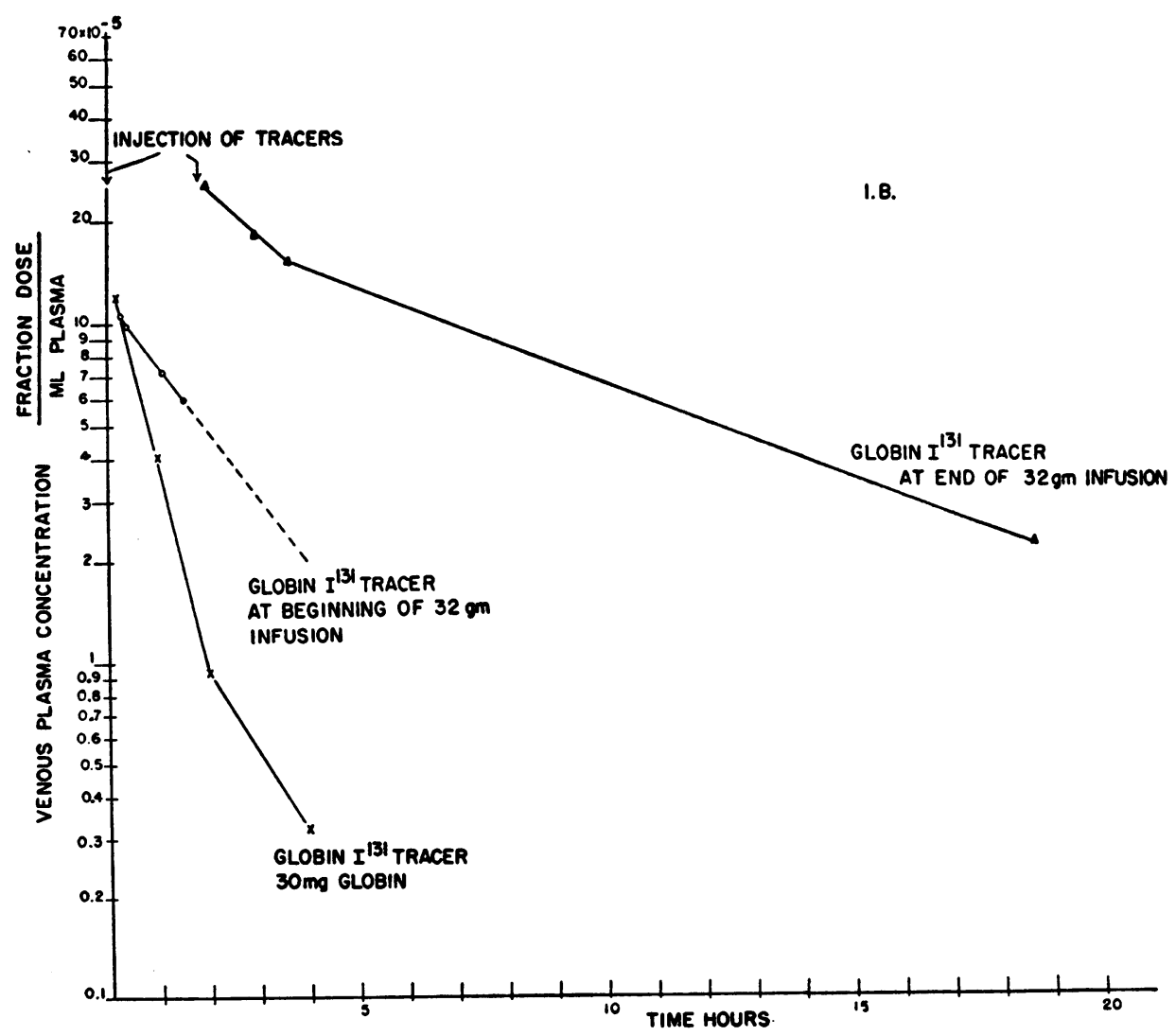

Fig. 5. Venous Plasma Concentrations of Tagged Globin Following Intravenous Injection of Globin-I ${ }^{131}$ with Different Carrier Loads of Globin in Subject I. B. 


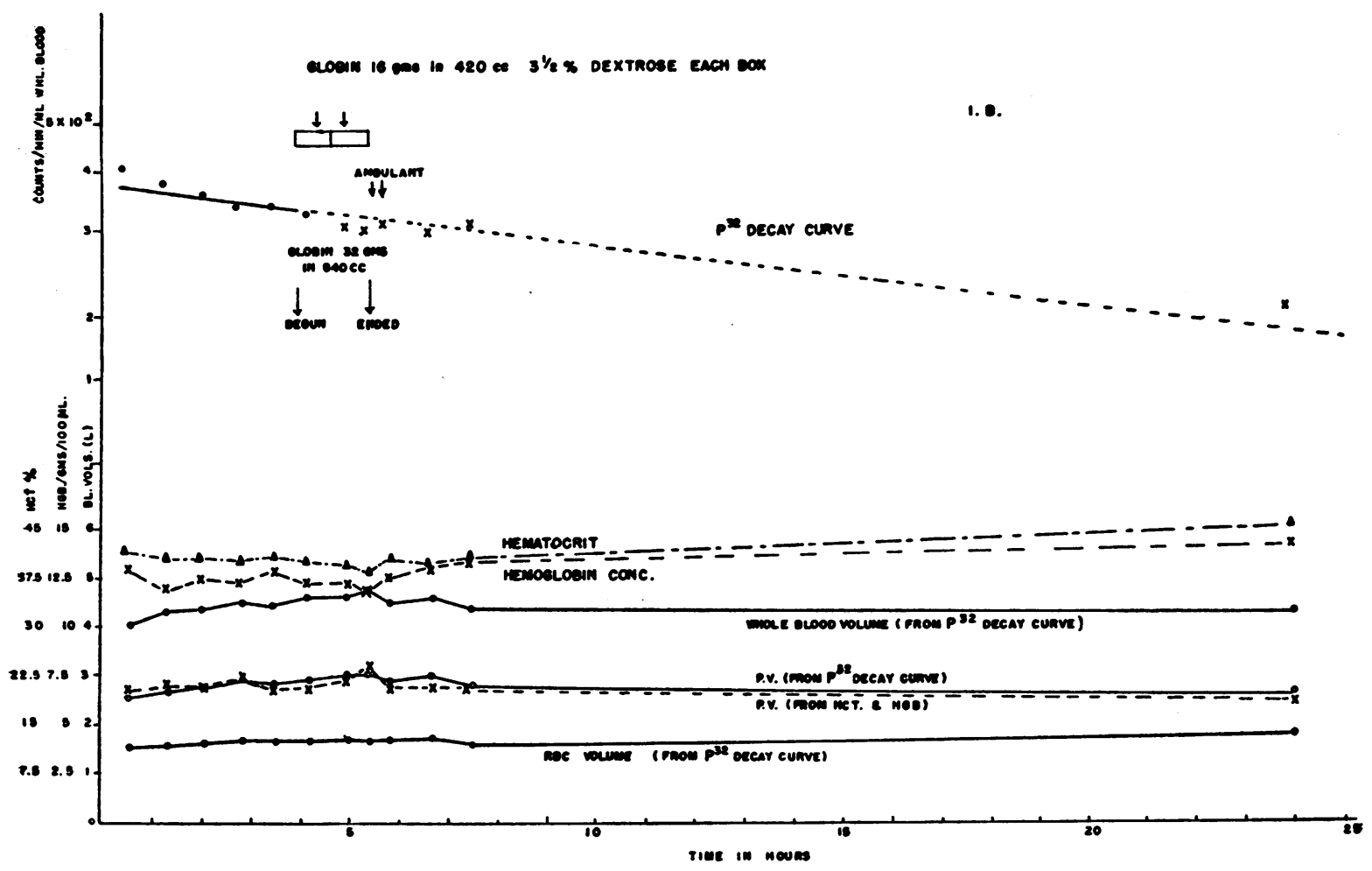

Fig. 6. Biological Decay Curve of Pz Labeled Erythrocytes, Hemoglobin Concentration, Hematocrit and Calculated Blood Volumes Before, During and After Intravenous Administration of 32 g. Globin In Subject I. B.

Since the rest period prior to the injection of the tagged cells was inadequate, there is an initial fall in $\mathrm{P}^{2}$ concentration, hematocrit and hemoglobin concentration due to temporary, continued hemodilution in the recumbent position. The reverse phenomenon (hemoconcentration) occurred during a brief period of unavoidable ambulation following discontinuance of the infusion.

centrations. This suggests that the globin is disappearing through some capillaries at a very rapid rate and that loss into these compartments is not prevented by the loading with large amounts of globin. Globin nitrogen could not even be detected in the plasma 18 hours after the termination of a $48 \mathrm{~g}$. infusion. The close parallel between the tagged and untagged globin curves validates the usefulness of the former in these studies. It may also be noted that significant amounts of $I^{131}$ were not present in the erythrocytes during the first $2 \frac{1}{2}$ hours.

Plasma levels of circulating globin following globin infusion

\begin{tabular}{|c|c|c|c|c|c|c|}
\hline Subject & $\begin{array}{c}\text { From onset of } \\
\text { infusion }\end{array}$ & $\begin{array}{c}\text { From end of } \\
\text { infusion }\end{array}$ & $\begin{array}{l}\text { Globin } \\
\text { infused }\end{array}$ & $\begin{array}{c}\text { Corrected } \\
\text { globin conc. }\end{array}$ & $\begin{array}{c}\text { Total } \\
\text { circulating } \\
\text { globin }\end{array}$ & $\begin{array}{l}\text { Dose } \\
\text { remaining } \\
\text { in plasma }\end{array}$ \\
\hline H. W. & $\begin{array}{l}1 \text { hr. } 5 \text { mins. } \\
1 \text { hr. } 45 \text { mins. } \\
2 \text { hrs. } 30 \text { mins. } \\
3 \text { hrs. } 15 \text { mins. } \\
20 \text { hrs. }\end{array}$ & $\begin{array}{l}40 \mathrm{~min} . \\
1 \mathrm{hr} .25 \text { mins. } \\
18 \mathrm{hrs} .10 \mathrm{mins} .\end{array}$ & $\begin{array}{l}g . \\
26 \\
44.8 \\
48 \\
48 \\
48\end{array}$ & $\begin{array}{c}\mathrm{mgm} . / \mathrm{ml} . \text { serum } \\
3.6 \\
3.1 \\
3.7 \\
3.6 \\
0\end{array}$ & $\begin{array}{c}g . \\
15.4 \\
13.2 \\
15.6 \\
15.2 \\
0\end{array}$ & $\begin{array}{c}\% \\
59.4 \\
29.4 \\
32.6 \\
31.7 \\
0\end{array}$ \\
\hline I. B. & $\begin{array}{l}1 \text { hr. } 50 \text { mins. } \\
2 \text { hrs. } 40 \text { mins. } \\
3 \text { hrs. } 30 \text { mins. } \\
20 \text { hrs. }\end{array}$ & $\begin{array}{l}20 \text { mins. } \\
50 \text { mins. } \\
2 \text { hrs. } \\
18 \frac{1}{2} \text { hrs. }\end{array}$ & $\begin{array}{l}32 \\
32 \\
32 \\
32\end{array}$ & $\begin{array}{l}5.0 \\
3.62 \\
4.66 \\
0\end{array}$ & $\begin{array}{c}14.0 \\
10.7 \\
12.8 \\
0\end{array}$ & $\begin{array}{c}43.6 \\
33.4 \\
39.8 \\
0\end{array}$ \\
\hline
\end{tabular}


Figures 5 and 6 illustrate the findings in similar experiments in subject I. B. Since this patient weighed 103 pounds, only $32 \mathrm{~g}$. of globin in $840 \mathrm{ml}$. solution was administered. The tracer dose without other globin (bottom curve Figure 5) was administered 13 days before the other two doses. The middle curve describes the findings when the tracer globin $\mathrm{I}^{\mathbf{1 3 1}}$ was administered immediately prior to the beginning of globin infusion. The concentration of activity following the globin $I^{131}$ injected at the end of the infusion is shown in the upper curve. Since the $\mathrm{I}^{131}$ activity from the latter 2 doses of globin $\mathrm{I}^{131}$ could not be distinguished, the upper curve was obtained by subtracting the extrapolated activities of the middle curve from the total activities. Here again there is a marked difference among the rates of disappearance of globin $\mathrm{I}^{131}$ at different carrier levels. In this case also, globin was not detectable by chemical analysis on the morning following the infusion ( $181 / 2$ hours after injec- tion). Table I summarizes the plasma globin data for H. W. and I. B.

In the experiments in which large amounts of carrier globin were administered together with tracer globin $\mathrm{I}^{131}$ an appreciable fraction of the early urinary losses of $\mathrm{I}^{131}$ was precipitable with trichloracetic acid (Figure 7), unlike the results obtained with the tracer doses alone. In the latter experiments the globin $\mathrm{I}^{\mathbf{1 3 1}}$ was removed from the plasma with such rapidity that within an hour or two there was virtually no circulating globin $I^{181}$ to filter through the glomeruli. However, when large doses of globin were administered concurrently with the tagged protein the plasma levels remained elevated for a longer period of time thus permitting larger amounts of undestroyed globin $\mathrm{I}^{131}$ to be excreted as such in the urine. The possibility that a renal threshold phenomenon could alone explain the findings is unlikely in view of the presence of some protein bound activity in the early urine specimens even

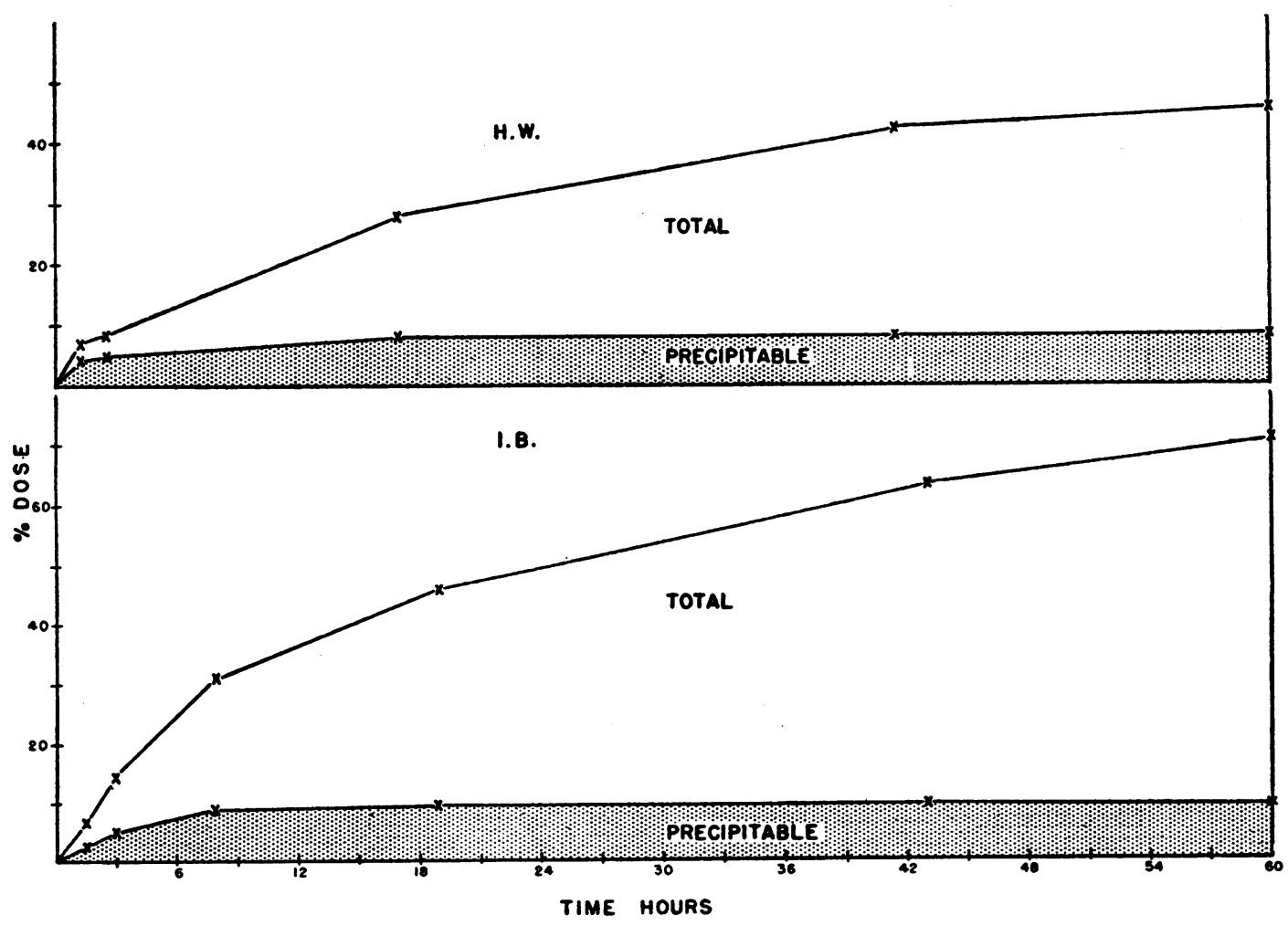

Fig. 7. Cumulative Urinary Excretion of Protein-Free and Protein-Bound I ${ }^{21}$ Following the Intravenous Administration of Tracer Doses of Globin-I ${ }^{191}$ Together with LaRge LoAds of UnTAGGED GLOBIN 

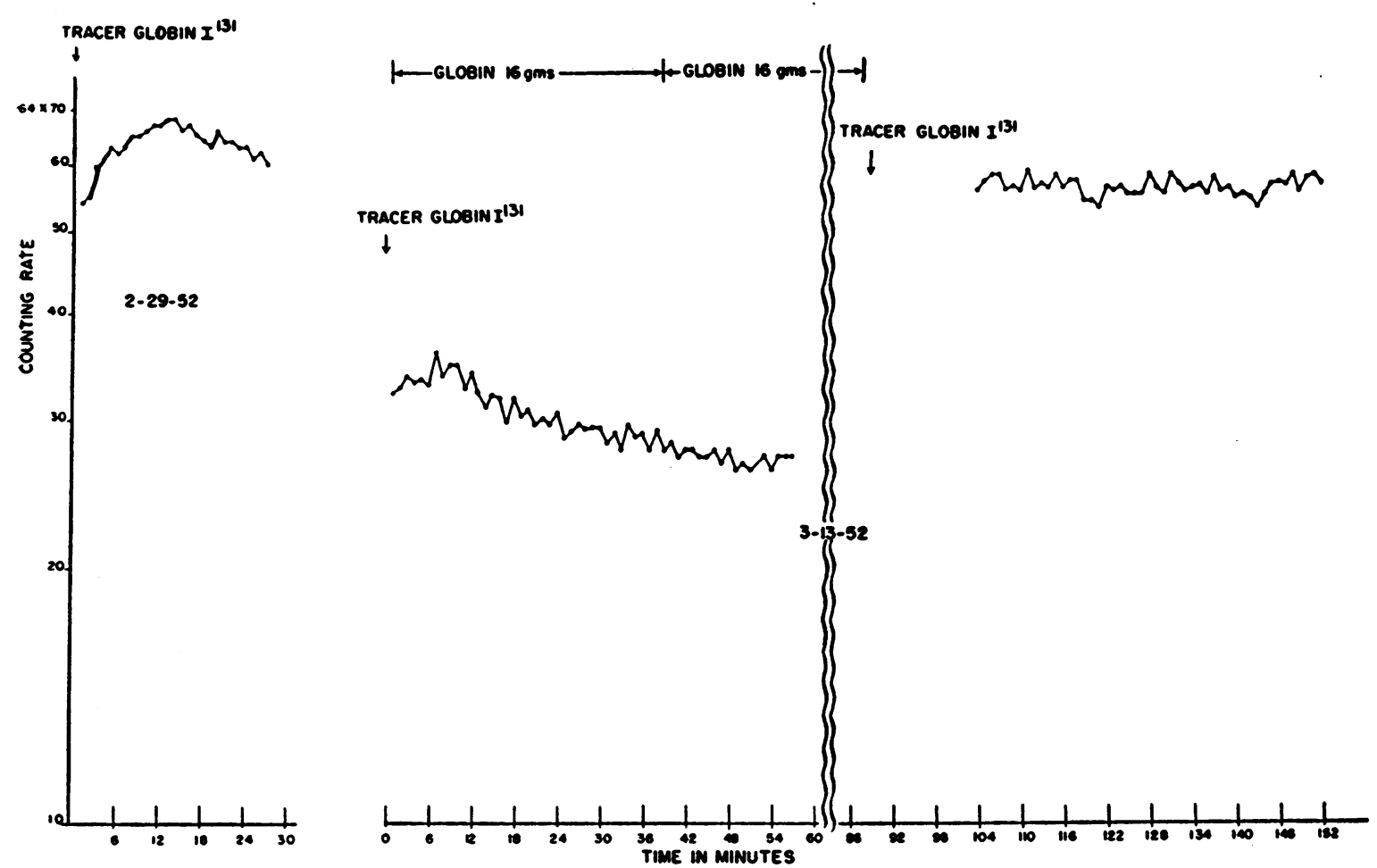

Fig. 8. Counting Rate Over the Liver Following the Intravenous Administration of Globin-I ${ }^{\text {ma }}$ With Different UntagGed Globin LoAdS

The first segment shows the changes when tracer globin- $\mathrm{I}^{121}$ alone was administered. The counting rates following the administration of globin- $\mathrm{I}^{121}$ at the beginning and at the end of a $32 \mathrm{~g}$. globin infusion are shown in the 2nd and 3rd segments respectively.

following the tracer doses which contained 30 mgm or less of protein.

Following administration of tracer globin $\mathrm{I}^{181}$ alone the radioactivity over the liver increased during the first 15 minutes and then gradually decreased (Figure 8). This pattern was confirmed by identical observations in another subject not included in this report and is suggestive of localization of globin in the liver followed by release of the non protein bound $\mathrm{I}^{131}$. After the first $1 / 4$ hour the inflow and outgo become nearly equal and the succeeding slower decrease in activity over the liver may be attributed to gradual losses from the body. The more modest rise in activity when the globin infusion immediately followed the injection of the tracer globin $\mathrm{I}^{131}$ may be attributed to a slowing down of hepatic accumulation due to the additional load. The absence of any significant decline in activity for an hour following the third tracer dose which was given immediately at the end of a 32 gram globin infusion is a more em- phatic demonstration of this "loading phenomenon." The differences in the plasma concentration curves following these 3 tracer doses may be taken as compatible with this view. Similar in vivo studies over the liver following albumin $\mathrm{I}^{181}$ injections showed no detectable change in counting rate over the first hour.

Figure 9 describes the disappearance of globin $I^{131}$ and albumin $I^{131}$ from muscle, skin and subcutaneous tissue. In most other globin $\mathrm{I}^{131}$ experiments and in some albumin $I^{181}$ studies two component curves were observed. In all cases (11 globin and 17 albumin experiments), the rate of disappearance of globin $\mathrm{I}^{131}$ was of the order of 6 to 12 times that of albumin $\mathrm{I}^{181}$. These experiments confirm the results of the plasma studies which sugested a more rapid loss of globin than albumin through capillaries in compartments other than the liver.

There were no untoward reactions following the globin administration. 


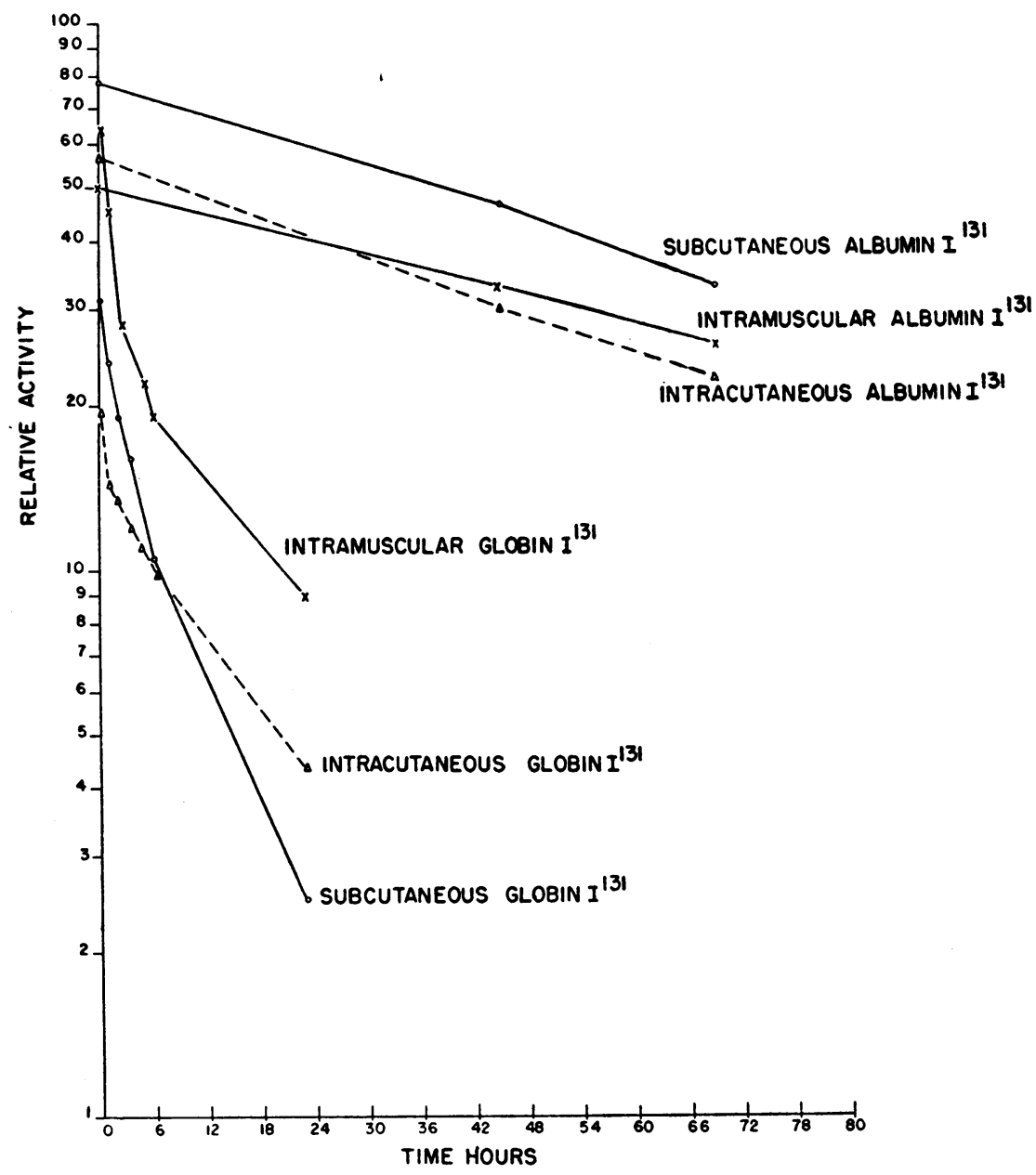

Fig. 9. Clearance of Tagged Globin and Albumin from Tissues

The ordinate represents the relative counting rates over the site of injection.

\section{DISCUSSION}

A detailed consideration of the mechanism of globin $I^{131}$ breakdown and of the release of the $\mathrm{I}^{131}$ is beyond the scope of this report. It may be suggested in brief, however, that release of mono-and diiodotyrosine occurs following proteolysis in the liver and that the subsequent metabolism of the amino acids with conversion of the $\mathrm{I}^{181}$ to iodide takes place with great rapidity as demonstrated by Albert and Keating (21).

The studies presented here suggest that globin is rapidly removed from plasma by the liver and by passage through capillaries throughout the body. While the relatively rapid clearance of globin $\mathrm{I}^{131}$ from injection sites in the skin, subcutaneous tissue and muscle of the lower extremities might be attributed to lymphatic drain- age the process is nevertheless very much slower with albumin $I^{131}$. These data suggest a marked difference in permeability of small vessels to the two proteins. The low initial globin $\mathrm{I}^{181}$ plasma concentrations (at 12 minutes), even following large doses of globin, offer further evidence on this point.

The retardation of the disappearance of globin $\mathrm{I}^{131}$ from plasma by large doses of globin and the differences observed in the in vivo hepatic counting rates at different dosage levels demonstrate the effect of loading on the ability of the liver to concentrate and break down the globin. However, even with relatively large doses of globin (32 to $48 \mathrm{~g}$.) the processes of removal and destruction were completed within a matter of hours. Under these conditions early urine specimens contained 
significant fractions of trichloracetic acid precipitable $\mathrm{I}^{181}$. The absence of such protein bound fractions after a few hours is further evidence of rapid disappearance of globin from the plasma.

The changes in plasma volume produced by the globin infusions were slight and in no way comparable to the increases which are observed regularly following albumin administration. In the 2 cases studied these changes could not be considered great enough to justify the use of globin in these amounts as a "plasma expander." The extremely rapid breakdown of the globin may indicate its usefulness as a ready source of amino acid nitrogen, but, if so, its superiority over protein hydrolysates has yet to be demonstrated.

\section{SUM MARY}

1. Radioiodinated modified human globin accompanied by varying amounts of carrier uniodinated globin was administered intravenously to human subjects. The rate of disappearance from plasma was inversely related to the quantity of globin administered. However even at the highest loads ( 32 to $48 \mathrm{~g}$. given in 2 hours) approximately one half to two thirds of the globin had left the plasma at the conclusion of the infusion.

2. When large amounts of globin were infused, a small percentage (approximately 10 per cent) was excreted as such in the urine, but the major portion was rapidly metabolized. Suggestive evidence for the liver as the site of metabolic degradation is presented.

3. From a comparative study of the rates of disappearance from sites of injection into skin, subcutaneous tissues and muscle it may be inferred that the capillary wall is much more permeable to globin than to albumin. Plasma studies confirm this.

4. The changes in circulating plasma volume produced by intravenous globin administration were slight and transient when compared to the effect of similar doses of human serum albumin. The studies reported here have failed to establish the clinical usefulness of globin as a plasma expander.

\section{REFERENCES}

1. Strumia, M. M., Chornock, F. W., Blake, A. D., and Kerr, W. G., The use of a "modified globin" from human erythrocytes as a plasma substitute; prelimi- nary report. Am. J. M. Sc., new series, 1945, 209, 436.

2. Strumia, M. M., Blake, A. D., Reider, H. C., and Chornock, F. W., The use of a "modified globin" from human erythrocytes in hypoproteinemias. Am. J. M. Sc., new series, 1946, 211, 51.

3. Brandt, J. L., Caccese, A., and Ginsberg, V., Effects of modified human globin in normal human subjects. Proc. Soc. Exper. Biol. \& Med., 1951, 77, 108.

4. Strumia, M. M., and Sample, A. B., Modified globin. I. Method for preparation from human erythrocytes. J. Lab. \& Clin. Med., 1951, 37, 959.

5. Brandt, J. L., and Caccese, A., The effects of modified human globin on renal function in cirrhosis of the liver. J. Lab. \& Clin. Med., 1952, 39, 57.

6. Vars, H. M., and Boxer, G. E., Modified globin. II. Chemical changes in human globin produced by alkaline modification. J. Lab. \& Clin. Med., 1952, 39, 743.

7. Waterhouse, C., Fenninger, L. D., and Keutmann, E. H., The use of modified globin as a protein supplement in normal individuals. Abstract, 44th Annual Meeting of the American Society for Clinical Investigation, p. 61, May 5, 1952.

8. Pennell, R. B., The preparation and characterization of modified human globin. Globin Conference, sponsored by Sharp and Dohme, Inc., April 2, 1951, Glenolden, Pennsylvania, pp. 8-11.

9. Pressman, D., and Eisen, $H$. N., The zone of localization of antibodies. V. An attempt to saturate antibody-binding sites in mouse kidney. J. Immunology, 1950, 64, 273.

10. Pressman, D., and Sternberger, L. A., The relative rates of iodination of serum components and the effect of iodination in antibody activity. J. Am. Chem. Soc., 1950, 72, 2226.

11. Berson, S. A., Yalow, R. S., Sorrentino, J., and Roswit, B., The determination of thyroidal and renal plasma $I^{131}$ clearance rates as a routine diagnostic test of thyroid dysfunction. J. Clin. Invest., 1952, $31,141$.

12. Berson, S. A., and Yalow, R. S., The use of $K^{42}$ or $P^{20}$ labeled erythrocytes and $I^{181}$ tagged human serum albumin in simultaneous blood volume determinations. J. Clin. Invest., 1952, 31, 572.

13. Vazquez, O. N., Newerly, K., Yalow, R. S., and Berson, S. A., Determination of trapped plasma in the centrifuged erythrocyte volume of normal human blood with radioiodinated ( $\mathrm{I}^{131}$ ) human serum albumin and radiosodium $\left(\mathrm{Na}^{24}\right)$. J. Lab. \& Clin. Med., 1952, 39, 595.

14. Boatman, J. B., and Moses, C., Role of erythrocyte in blood iodine transport using radioiodine $\mathrm{I}^{\mathrm{m}}$. Am. J. Physiol., 1951, 164, 783.

15. Sample, A. B., Strumia, M. M., and Satta, V., Modified globin in blood serum and in urine. J. Lab. \& Clin. Med., 1952, 40, 206. 
16. Wisham, L. H., and Yalow, R. S., Some factors affecting the clearance of $\mathrm{Na}^{2}$ from human muscle. Am. Heart J., 1952, 43, 67.

17. Yalow, $R$.S., and Berson, S. A., The use of $\mathrm{K}^{2}$ tagged erythrocytes in blood volume determinations. Science, 1951, 114, 14.

18. Berson, S. A., Yalow, R. S., Azulay, A., Schreiber, S., and Roswit, B., The biological decay curve of $P^{w}$ tagged erythrocytes. Application to the study of acute changes in blood volume. J. Clin. Invest., 1952, 31, 581.
19. Welt, L. G., and Orloff, J., The effects of an increase in plasma volume on the metabolism and excretion of water and electrolytes by normal subjects. J. Clin. Invest., 1951, 30, 751.

20. Wong, S. Y., Colorimetric determination of iron and hemoglobin in blood. II. J. Biol. Chem., 1928, 77, 409.

21. Albert, A., and Keating, F. R., Jr., Metabolic studies with $\mathrm{I}^{131}$ labeled thyroid compounds: Distribution and excretion of radiodiiodotyrosine in human beings. J. Clin. Endocrinol., 1951, 11, 996. 